\title{
Absence of Islet Alpha Cell Function in Pancreatectomized Patients
}

\author{
A. Tiengo ${ }^{1}$, M. Bessioud ${ }^{2}$, I. Valverde 3 , A. Tabbi-Anneni' ${ }^{2}$, S. Delprato' ${ }^{1}$ J. Alexandre ${ }^{4}$ and R. Assan ${ }^{2}$ \\ ${ }^{1}$ University of Padova, Italy; ${ }^{2}$ Diabetes Department, Hôpital Bichat, Paris, France; ${ }^{3}$ Fundation Jimenez Diaz, Madrid, Spain; \\ ${ }^{4}$ Department of Surgery, Hôpital Broussais, Paris, France
}

\begin{abstract}
Summary. Plasma immunoreactive glucagon, C-peptide and substrates (glucose, lactate, and alanine) were measured in 21 pancreatectomized patients and 28 patients with chronic calcifying pancreatitis during arginine infusion. Results were compared with those obtained in control and in insulin-dependent diabetic subjects, and in pancreatectomized subjects receiving a combined infusion of glucagon and arginine or somatostatin and arginine. Plasma immunoreactive glucagon in the pancreatectomized patients was $230 \pm 26 \mathrm{pg} / \mathrm{ml}$ (control subjects $100 \pm 13 \mathrm{pg} / \mathrm{ml}$, $p<0.001$ ), but was unchanged following arginine or somatostatin. Following ethanol extraction of plasma it became undetectable. Similar results were obtained in patients with chronic pancreatitis. In contrast to the insulin-dependent diabetic subjects, no changes in blood glucose, lactate, and alanine concentrations were found during arginine infusion in the pancreatectomized or pancreatitis patients. Addition of glucagon restored the metabolic response to arginine in the pancreatectomized patients. Our results confirm previous smaller studies that in pancreatectomized patients, A cell function is absent or insignificant.
\end{abstract}

Key words: Glucagon, A cell, pancreatectomy, diabetes, arginine, somatostatin, pancreatitis, glucose, big plasma glucagon.

It is well established that in several animal species glucagon-like material can be released from extra-pancreatic sites [1-6]. In the dog, the stomach produces substantial amounts of glucagon which is immunologically [7] and biologically $[8,9]$ indistinguishable from pancreatic glucagon. In human subjects, however, the situation is less clear, although several authors have considered that pancreatectomized sub- jects represent a model of diabetes without glucagon [10-12]. The final solution of this problem is fraught with difficulties: 1) totally pancreatectomized subjects are not often available for metabolic and hormonal studies; 2) in many cases, the stomach and duodenum, as potential sources of extra-pancreatic glucagon [13], have been removed with the pancreas; and 3) cross-reacting substances of gastrointestinal origin $[14,15]$ and the presence in plasma of an interfering globulin [16] or 'big plasma glucagon' [17] may render the interpretation of radioimmunoassays difficult. In order to clarify this problem, 21 pancreatectomized subjects were submitted to arginine infusion and plasma glucagon immunoreactivity (IRG) was measured with a C-terminal antibody before and after ethanol extraction. The metabolic responses to arginine were assessed by measurement of blood glucose, lactate and alanine levels. The patients were compared with normal subjects, patients with chronic calcifying pancreatitis, and insulin-dependent diabetics free of detectable chronic pancreatitis.

\section{Subjects and Methods}

\section{Subjects}

The main clinical characteristics of the subjects are shown in Table 1. Of the 21 pancreatectomized subjects, two had undergone operation because of exocrine pancreatic carcinoma, and one because of an intractable juxtaduodenal insulinoma. All the others had presented either with acute necrotizing pancreatitis or with a chronic pancreatitis. Total pancreatectomy was performed by a standardised technique, totally removing the pancreatic gland, the duodenum, the spleen and the antropyloric two-thirds of the stomach [18]. In the second group the diagnosis of chronic pancreatitis was based on the presence of chronic diarrhoea and steatorrhoea, abdominal pain, and radiological evidence of pancreatic calcification. Most of these patients were chronic abusers of ethanol. Six had been submitted to a partial resection (four-fifths) of the pan- 
Table 1. Clinical details of the groups studied

\begin{tabular}{llclll}
\hline Group & Age (years) & Sex $(\mathrm{M}: \mathrm{F})$ & $\begin{array}{l}\text { \% Ideal body } \\
\text { weight }\end{array}$ & $\begin{array}{l}\text { Duration of the } \\
\text { disease (years) }\end{array}$ & $\begin{array}{l}\text { Daily insulin } \\
\text { dose }(\mathrm{U})\end{array}$ \\
\hline Control subjects $(n=31)$ & $36 \pm 3$ & $15: 16$ & $99 \pm 1$ & - & - \\
Pancreatectomized subjects $(n=21)$ & $39 \pm 4$ & $10: 11$ & $97 \pm 1$ & $2 \pm 1$ & $35 \pm 6$ \\
Chronic pancreatitis $(n=28)$ & $52 \pm 2$ & $18: 10$ & $93 \pm 3$ & $7 \pm 3$ & $30 \pm 8$ \\
Diabetic subjects $(n=12)$ & $42 \pm 2$ & $6: 6$ & $96 \pm 3$ & $7 \pm 2$ & $50 \pm 4$ \\
\hline
\end{tabular}

Table 2. Basal values $(08.00 \mathrm{~h})$ for circulating substrates and hormones in the groups studied

\begin{tabular}{|c|c|c|c|c|c|c|}
\hline Group & $\begin{array}{l}\text { Blood } \\
\text { glucose } \\
(\mathrm{mmol} / 1)\end{array}$ & $\begin{array}{l}\text { Blood } \\
\text { lactate } \\
(\mathrm{mmol} / 1)\end{array}$ & $\begin{array}{l}\text { Blood } \\
\text { alanine } \\
(\mathrm{mmol} / 1)\end{array}$ & $\begin{array}{l}\text { Plasma IRG } \\
\text { Unextracted plasma } \\
(\mathrm{pg} / \mathrm{ml})\end{array}$ & $\begin{array}{l}\text { Plasma IRG } \\
\text { Extracted plasma } \\
(\mathrm{pg} / \mathrm{ml})\end{array}$ & $\begin{array}{l}\text { Plasma } \\
\text { C-peptide } \\
(\mathrm{ng} / \mathrm{ml})\end{array}$ \\
\hline Control subjects $(n=31)$ & $4.4 \pm 0.1$ & $0.80 \pm 0.01$ & $0.47 \pm 0.03$ & $100 \pm 13$ & $45 \pm 5$ & $2.80 \pm 0.20$ \\
\hline $\begin{array}{l}\text { Pancreatectomized } \\
\text { subjects }(n=21)\end{array}$ & $8.7 \pm 1.0^{\mathrm{c}}$ & $1.86 \pm 0.13^{c}$ & $0.60 \pm 0.05^{\mathrm{a}}$ & $230 \pm 26^{c}$ & $28 \pm 5^{\mathrm{a}}$ & $0.22 \pm 0.05^{\mathrm{c}}$ \\
\hline Chronic pancreatitis $(n=28)$ & $8.7 \pm 0.8^{c}$ & $1.35 \pm 0.08^{\mathrm{c}}$ & $0.78 \pm 0.09^{\mathrm{b}}$ & $242 \pm 13^{c}$ & $48 \pm 10$ & $0.72 \pm 0.10^{\mathrm{c}}$ \\
\hline Diabetic subjects ( $n=12$ ) & $8.7 \pm 1.6^{c}$ & $0.82 \pm 0.05$ & $0.58 \pm 0.14$ & $191 \pm 26^{\mathrm{c}}$ & $135 \pm 29^{\mathfrak{c}}$ & $0.99 \pm 0.10^{c}$ \\
\hline
\end{tabular}

Results are presented as mean values \pm SEM

Significance of differences from control values is denoted by: ${ }^{a} p<0.05,{ }^{b} p<0.01,{ }^{c} p<0.001$

creas, but gastrectomy had been performed in none of them. Liver function was assessed by measurement of the coagulation factors, of serum alkaline phosphatase concentration and bromsulphthalein excretion. The third group consisted of insulin-dependent diabetic patients, free of detectable chronic calcifying pancreatitis. Insulin was administered as either two daily injections of Rapitard insulin or three daily injections of Actrapid insulin, the last dose being given at $20.00 \mathrm{~h}, 12 \mathrm{~h}$ before the tests (unless otherwise stated). Pancreatectomized patients and subjects with chronic pancreatitis were placed on a carbohydrate-rich $(300 \mathrm{~g} /$ day) and low fat $(20 \mathrm{~g} /$ day) isocaloric diet. None of them received biguanides or drugs other than insulin. Pancreatic enzyme supplements (Eurobiol) were administered routinely to all pancreatectomized and pancreatitis patients. Tests were performed at $08.00 \mathrm{~h}$ after an overnight fast, the morning insulin injection being omitted. Chronic pancreatitis patients with chronic ethanol ingestion had been abstinent for at least $12 \mathrm{~h}$. Informed consent was obtained from all subjects and the investigation was approved by the INSERM Ethical Committee.

\section{Protocol}

Arginine infusion test: Arginine $\mathrm{HCl}(25 \mathrm{~g})$, dissolved in $400 \mathrm{ml}$ sterile water, was infused at constant flow rate for $30 \mathrm{~min}$ into an antecubital vein, using an Infusomat pump (Braun, Melsungen, FGR). Blood samples were obtained from a contralateral ante-cubital vein, two to four basal samples being collected during the $30 \mathrm{~min}$ before infusion, then at 15,30,45,60 and 90 min after the start of infusion. Blood samples $(5 \mathrm{ml}$ each) were drawn with a heparinized syringe and distributed into chilled tubes, containing $2000 \mathrm{U}$ aprotinin (Trasylol) and $1.2 \mathrm{mg}$ EDTA/ $\mathrm{ml}$ blood for hormone assays or $1 \mathrm{ml}$ of $10 \%$ perchloric acid $/ \mathrm{ml}$ blood for substrate determinations. Samples were centrifuged at $+4{ }^{\circ} \mathrm{C}$, then the plasma was rapidly frozen and kept at $-20^{\circ} \mathrm{C}$ until assay. A total of 31 control subjects, 21 pancreatectomized patients, 28 with chronic pancreatitis and 12 diabetic subjects free of detectable pancreatitis were tested.

Somatostatin + Arginine infusion: Cyclic somatostatin (Clin Midy, Paris, France) was dissolved in $0.154 \mathrm{~mol} / 1$ saline solution immedi- ately before use. It was then injected IV as a bolus of $1 \mathrm{mg}$ followed by an infusion of $1 \mathrm{mg}$ over $30 \mathrm{~min}$, at a constant flow rate, mixed with arginine; four control subjects and eight pancreatectomized subjects underwent this test.

Glucagon + Arginine infusion: Crystalline glucagon (Novo, Copenhagen) was dissolved in $0.154 \mathrm{~mol} / 1$ saline solution immediately before use. A bolus IV dose of $8 \mu \mathrm{g}$ was given, followed by $0.57 \mu \mathrm{g} / \mathrm{min}$ for $30 \mathrm{~min}$, mixed with arginine. These doses have been shown to produce glucagon concentrations in plasma comparable to those measured in uncontrolled diabetic patients [19]. Four pancreatectomized patients received this infusion.

Other tests: Arginine ( $25 \mathrm{~g})$ was administered orally, after an overnight fast, to six pancreatectomized patients; glucose $(50 \mathrm{~g})$ to four pancreatectomized patients. Interruption of insulin therapy for $36 \mathrm{~h}$ was performed in one pancreatectomized patient, after which a IV arginine infusion was performed.

\section{Assays}

Glucagon immunoreactivity: IRG was determined in plasma samples using the $30 \mathrm{~K}$ antiserum (Dr. R. H. Unger, Dallas, Texas) [20] the standard curves being constructed in $0.2 \mathrm{~mol} / 1$ glycine buffer containing $5 \mathrm{~g} / 1$ serum albumin and $10 \mathrm{~g} / 1$ sheep serum. The lowest amount of glucagon standard which gave a significant variation of the bound/free ratio from the zero standard was $7 \mathrm{pg} / \mathrm{ml}$, corresponding in whole plasma to a detection limit of $21 \mathrm{pg} / \mathrm{ml}$. Interassay variation was less than $5 \%$. Aliquots of plasma were also submitted to ethanol fractionation [21]: $0.2 \mathrm{ml}$ plasma were mixed with $0.36 \mathrm{ml}$ ethanol $96 \%(\mathrm{v} / \mathrm{v})$ at $5{ }^{\circ} \mathrm{C}$, then centrifuged at $4{ }^{\circ} \mathrm{C}$; the supernatant was lyophilized and resuspended in $0.2 \mathrm{ml}$ glycine buffer $(0.2 \mathrm{~mol} / 1, \mathrm{pH} 8.6)$ containing $2.5 \mathrm{~g} / 1$ bovine serum albumin. $\mathrm{Re}-$ covery was $75 \%-85 \%$ : the values determined after the extraction procedure were corrected accordingly.

Other methods: C-peptide was determined [23] using an antiserum directed against human synthetic C-peptide (BYK. Mallinckrod, Dietzenbach, FGR); the lowest amount of $\mathrm{C}$-peptide standard giv- 
ing a significant variation of the bound/free ratio from zero standard was $0.2 \mathrm{ng} / \mathrm{ml}$ (whole plasma). The inter-assay variation was less than $4 \%$.

Glucose was measured by a glucose-oxidase method [24] adapted for the Beckman analyzer (glucose analyzer Mark $3 \mathrm{G} \mathrm{A}$, Beckman Instruments, Fullerton, $\mathrm{CA}$ ). Alanine and lactate were determined by enzymatic methods $[25,26]$.

\section{Calculations}

Results are presented as mean \pm SEM. Statistical analysis was performed employing Student's t test for unpaired samples [27].

\section{Results}

\section{Basal Values (Table 2)}

After an overnight fast, blood glucose was significantly higher in all diabetic groups than in control subjects. Blood lactate and alanine were significantly higher in both the pancreatectomized patients and the subjects with chronic pancreatitis than in the two other groups. This difference was particularly marked for lactate in the pancreatectomized group.

Plasma C-peptide values were lower in all diabetic groups than in control subjects. In all pancreatectomized patients they were undetectable. Plasma IRG levels in unextracted plasma samples were significantly higher in all diabetic groups than in the control subjects. However, following extraction by ethanol, IRG levels were $28 \pm 5 \mathrm{pg} / \mathrm{ml}$ in the pancreatectomized patients, almost at the limit of sensitivity and significantly lower than in control subjects $(p<0.001)$. In the patients with chronic pancreatitis, extracted plasma IRG levels were not significantly different from controls: $45 \pm 5$ versus $48 \pm 10 \mathrm{pg} / \mathrm{ml}$. Liver function tests were within normal limits in all subjects.

\section{Arginine Infusion Test}

In control subjects (Fig. 1) arginine infusion induced the expected significant rise in C-peptide and IRG concentrations. Blood lactate decreased significantly, while no significant changes occurred in glucose and alanine.

In the insulin-dependent patients arginine induced a rise in glucagon concentration, more pronounced than in controls, while the C-peptide level remained lower than normal and did not increase significantly. Blood glucose rose, while lactate and alanine concentrations declined, these changes being significant and related in time to the rise of plasma IRG.

In the pancreatectomized patients (Fig. 2) plasma IRG (unextracted samples) did not change signifi-

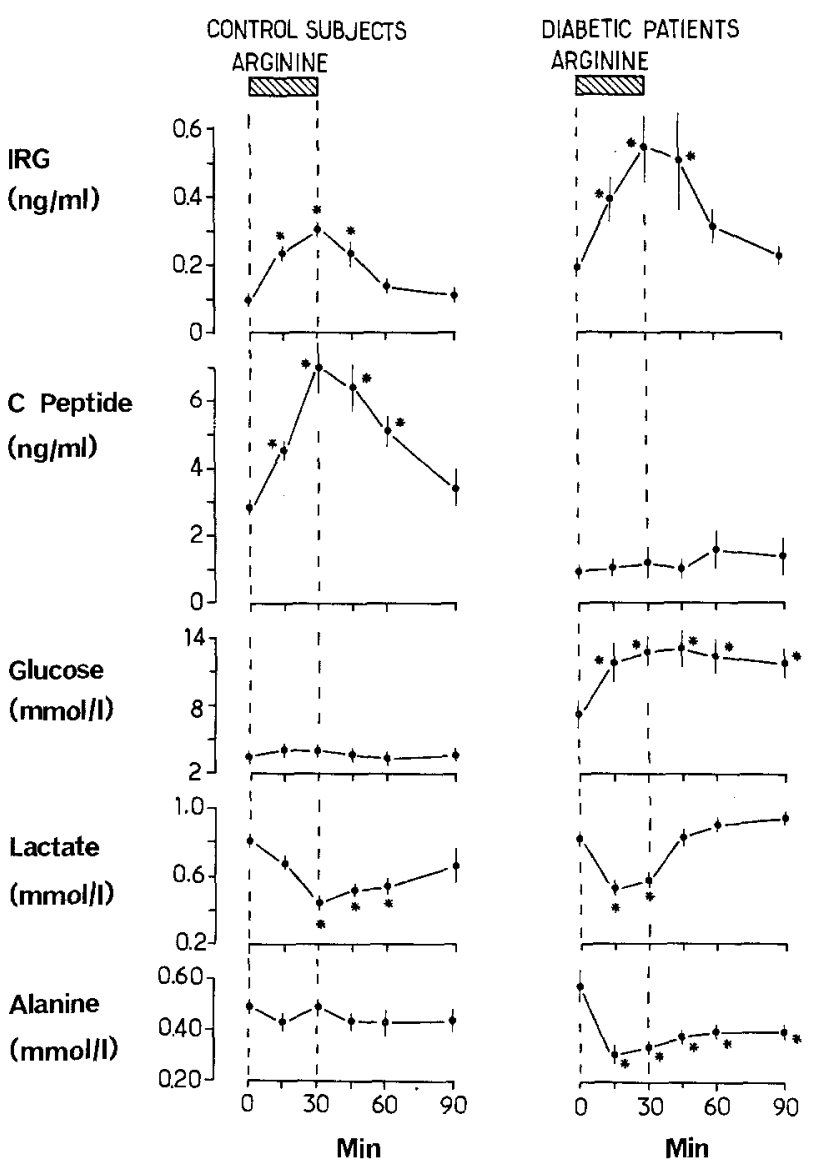

Fig. 1. Effect of arginine infusion on plasma hormone and blood substrate concentrations in control subjects $(n=15)$ and insulindependent diabetics $(n=17)$. $\mathbb{*}=$ arginine infusion. Results are presented as mean values \pm SEM. * statistical significance of differences with basal value in the same group $(p<0.01)$. Basal values were calculated as the mean of results in two to six samples collected for the $30 \mathrm{~min}$ pre-infusion period in each patient. Plasma glucagon (IRG) values are given for samples not submitted to extraction with ethanol

cantly during the arginine infusion. C-peptide levels remained undetectable. No significant changes in blood glucose, lactate and alanine concentrations were found. The subjects with chronic pancreatitis displayed a pattern similar to that of pancreatectomized patients. However, a slight but significant rise of IRG level occurred at 30 and $90 \mathrm{~min}(p<0.05)$; Cpeptide values, although measurable, did not rise. Blood glucose, lactate and alanine concentrations did not change significantly.

The pattern of plasma IRG was markedly changed by ethanol extraction of samples (Fig. 3). In control subjects, IRG values in extracted samples rose acutely during the stimulation period and were not different from the values obtained before extraction over this period. In contrast, extractable IRG in the pancreatectomized patients remained below the 


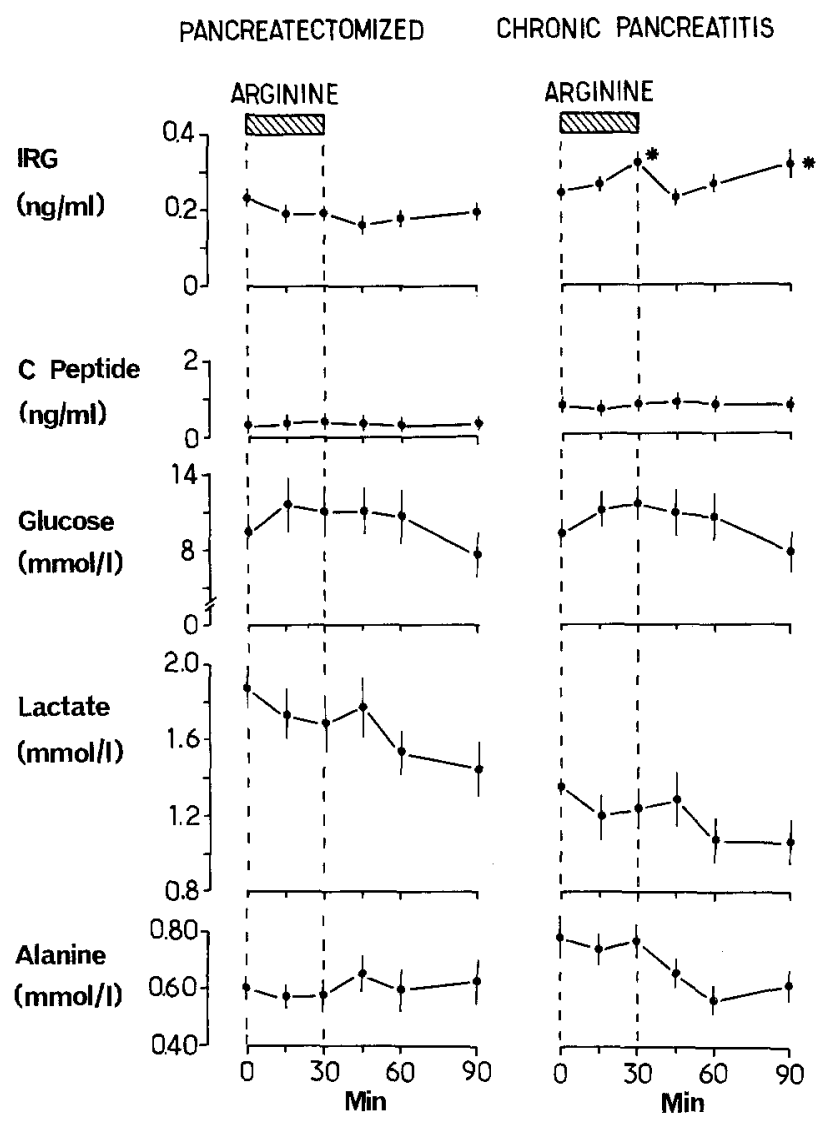

Fig. 2. Effect of arginine infusion on plasma hormone and blood substrate concentrations in pancreatectomized patients $(n=21)$ and patients with a chronic pancreatitis $(n=28)$. Same presentation as in Fig. 1

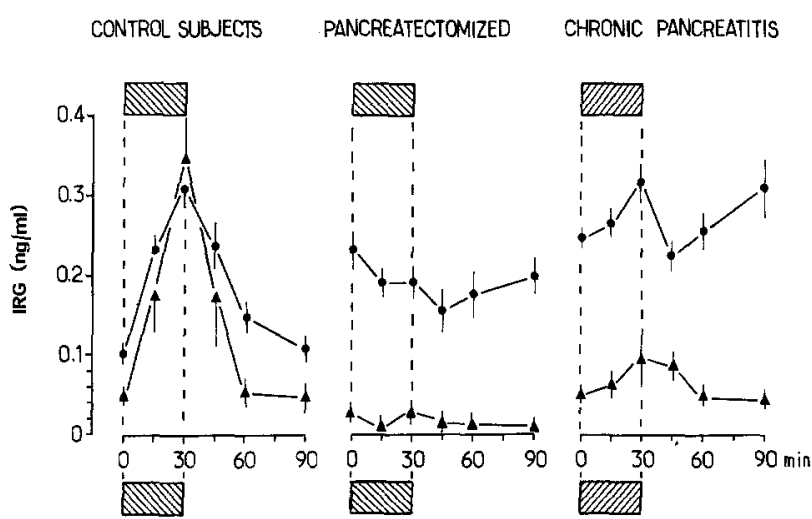

Fig. 3. Effect of arginine infusion on glucagon (IRG) concentrations measured in plasma samples before $(0)$ and after $(\boldsymbol{A})$ extraction with ethanol in 31 control subjects, 21 pancreatectomized patients and 28 patients with chronic pancreatitis. Same presentation as in Fig. 1

limit of sensitivity of the assay and did not rise during the stimulatory period. In the patients with pancreatitis, values were higher than in the pancreatectomized patients but did not change significantly (Fig. 3).

\section{Somatostatin + Arginine, and Glucagon + Arginine Infusions}

As shown in Figure 4, addition of somatostatin to the arginine infusion did not modify the pattern observed in the pancreatectomized patients. No change was found in plasma IRG, blood glucose, lactate, alanine and plasma C-peptide concentrations. In control subjects, the same combined infusion induced the expected suppression of IRG and C-peptide levels followed by a rebound at the end of infusion. In contrast, when exogenous glucagon was added to the arginine infusion in pancreatectomized subjects, a significant increase in blood glucose occurred, accompanied by significant decreases in blood lactate and alanine concentrations.

\section{Other Tests}

Interruption of insulin therapy: In one pancreatectomized patient, insulin therapy was interrupted for $36 \mathrm{~h}$, and this patient was submitted to a complete fast for $24 \mathrm{~h}$. At end of this period, IRG concentration in plasma (unextracted samples) was $318 \mathrm{pg} / \mathrm{ml}$ (mean of two samples; NS versus overnight fasting state). Arginine infusion test at that time, when blood glucose was $23 \mathrm{mmol} / 1$, did not induce any rise in IRG.

Ingestion of arginine (Table 3): Oral ingestion of $25 \mathrm{~g}$ arginine $\mathrm{HCl}$ did not significantly modify the plasma IRG concentration in six pancreatectomized patients.

Oral glucose tolerance test (Table 3): Ingestion of $50 \mathrm{~g}$ glucose induced, in a group of four pancreatectomized subjects, a slight but significant increase in IRG concentration $(p<0.05)$, as measured by the $30 \mathrm{~K}$ antiserum in plasma samples not submitted to extraction by ethanol.

\section{Discussion}

Our results show that in pancreatectomized patients plasma IRG was detectable before ethanol extraction but disappeared or remained close to the limit of assay sensitivity following this extraction. Furthermore, plasma IRG in unextracted samples did not rise during arginine infusion in these patients and remained barely detectable in extracted samples. Somatostatin infusion did not influence this pattern in eight patients. The modifications of blood glucose, lactate, alanine which follow arginine infusion in insulin-dependent diabetics were not observed in the pancreatectomized group, suggesting the absence of release of biologically active glucagon. In the patients with 
chronic pancreatitis, whose stomachs were still present, the hormonal and metabolic pattern was very similar to that observed in pancreatectomized (and partially gastrectomized) patients. Infusion of exogenous glucagon in pancreatectomized subjects reproduced the changes in glucose, lactate and alanine which are observed when endogenous glucagon is released under influence of IV arginine, in the absence of any

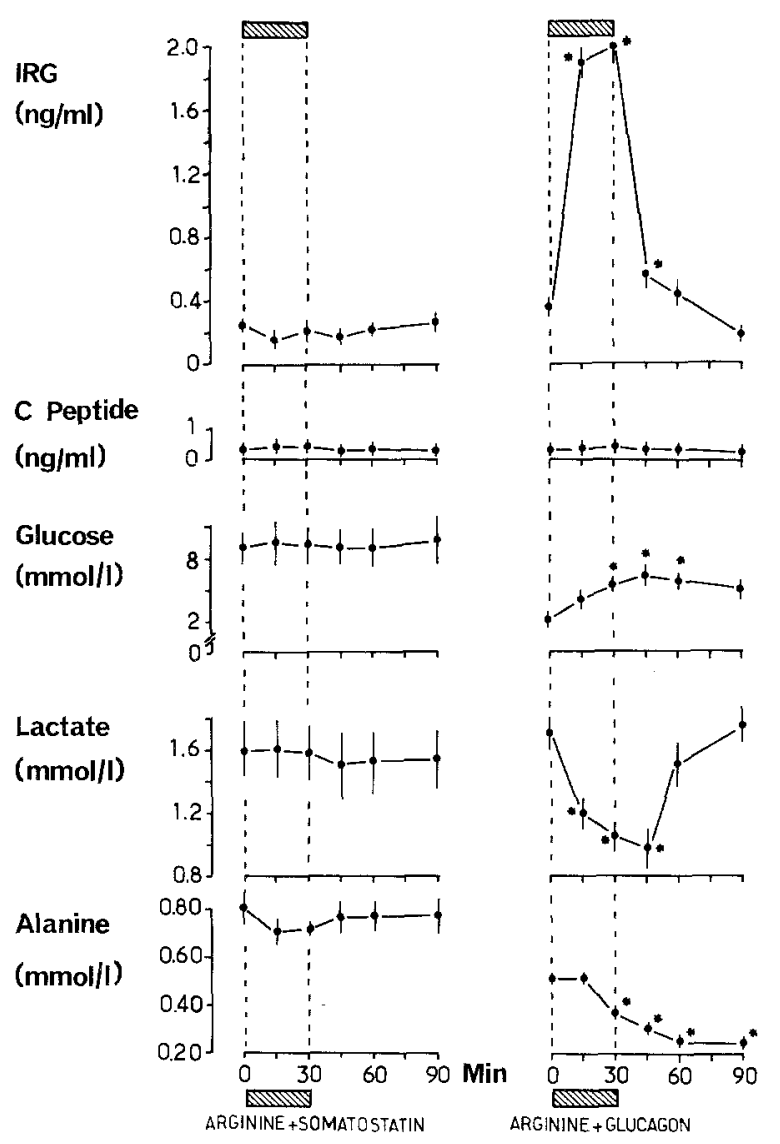

Fig. 4. Effect of arginine infusion on plasma hormone and blood substrate concentrations in pancreatectomized patients submitted concomittantly to an IV infusion of somatostatin (left panel, $n=8$ ) and an IV infusion of glucagon (right panel, $n=4$ ). Same presentation as in Fig. 1 concomitant insulin release. These points are consistent with the concept of an exclusive pancreatic source of glucagon in man.

At least 17 papers have been published on the debated point of extra-pancreatic glucagon in man, based on approximately 52 pancreatectomized subjects and 65 patients with chronic pancreatitis and/or partial resection of the pancreas (Table 4). The majority of published results suggest that extra-pancreatic sources of immunoreactive and biologically active glucagon are insignificant in man: plasma glucagon in the basal state was either undetectable, or significantly lower than in normal and in diabetic subjects $[9,11,12,15,29-36]$. Furthermore a deficient or absent plasma IRG response occurred following IV infusion of amino acids $[9,11,15,28,30,33,34,36]$, interruption of insulin therapy [9] or insulin-induced hypoglycaemia $[29,30]$. This latter test is however less meaningful than the others, since diabetic A cells are not as sensitive to hypoglycaemia as normal A cells [37]. The lack of suppression of plasma IRG by somatostatin [34] is another line of evidence for the non-hormonal nature of 'big plasma glucagon'. In most of these papers a C-terminal antiserum was used, usually the $30 \mathrm{~K}$ antiserum, and various procedures were employed to avoid non-specific plasma interference. These include extraction procedures $[9,11,12,15,31$, $33,38]$ and/or construction of standard curves with 'deglucagonized' plasma $[9,11]$. It must be emphasized, however, that proving the absence of a factor is much more difficult and problematic than confirmation of its existence. The particular metabolic features observed in these patients may be more significant. These include high blood alanine levels in the basal state [38], the delayed rise of blood glucose and ketone bodies following cessation of insulin therapy $[9,12]$ and the absence of a rise in blood glucose during arginine infusion $[6,11,15,34]$. The present study is consistent with these previous results and documents further the presence of high lactate levels in the basal state and the persistence of blood alanine during arginine infusion. These metabolic features may repre-

Table 3. Plasma IRG values (pg/ml; unextracted plasma samples) measured in pancreatectomized patients submitted to an oral arginine load and oral glucose tolerance test

\begin{tabular}{|c|c|c|c|c|c|c|c|c|c|}
\hline & \multicolumn{9}{|c|}{ Time (min) } \\
\hline & -15 & 0 & 15 & 30 & 45 & 60 & 75 & 90 & 120 \\
\hline $\begin{array}{l}\text { Oral arginine load }(25 \mathrm{~g}) \\
(n=6)\end{array}$ & $190 \pm 42$ & $187 \pm 41$ & $199 \pm 45$ & $207 \pm 41$ & $207 \pm 45$ & $307 \pm 82$ & $223 \pm 45$ & $214 \pm 26$ & $229 \pm 42$ \\
\hline $\begin{array}{l}\text { Oral glucose tolerance test } \\
(50 \mathrm{~g})(n=4)\end{array}$ & $140 \pm 34$ & $149 \pm 30$ & $185 \pm 42$ & $260^{\mathrm{a}} \pm 38$ & $216 \pm 42$ & $236 \pm 39$ & $213 \pm 28$ & $180 \pm 50$ & $165 \pm 27$ \\
\hline
\end{tabular}

Results are presented as mean values \pm SEM

${ }^{a} p<0.05$ versus basal value in corresponding group 
Table 4. Published studies of plasma IRG in pancreatectomized patients and patients with pancreatitis. Numbers in parentheses correspond to bibliography of present paper

\begin{tabular}{|c|c|c|c|c|c|c|}
\hline Reference & $\begin{array}{l}\text { No. of } \\
\text { patients }\end{array}$ & Antiserum used & $\begin{array}{l}\text { Extraction } \\
\text { procedure }\end{array}$ & Tests used & IRG changes & Metabolic changes \\
\hline \multicolumn{7}{|l|}{ Pancreatectomized patients } \\
\hline Müller et al. $[11,15]$ & 5 & $\begin{array}{l}\mathrm{C} \text {-terminal and } \\
\mathrm{N} \text {-terminal }\end{array}$ & Charcoal & Arginine & $\begin{array}{l}\text { Lower IRG } \\
\text { reduced rise }\end{array}$ & No glucose rise \\
\hline Villanueva et al. [33] & 1 & C-terminal & $\begin{array}{l}\text { Biogel }+ \\
\text { charcoal }\end{array}$ & Arginine & No rise & \\
\hline Barnes et al. $[9,12]$ & 5 & C-terminal & $\begin{array}{l}\text { Affinity } \\
\text { chromatog- } \\
\text { raphy }\end{array}$ & $\begin{array}{l}\text { Arginine; } \\
\text { Interruption of } \\
\text { insulin treatment }\end{array}$ & $\begin{array}{l}\text { Basal IRG = zero } \\
\text { No rise }\end{array}$ & $\begin{array}{l}\text { No glucose rise } \\
\text { (arginine) } \\
\text { Delayed glucose } \\
\text { and ketone rise }\end{array}$ \\
\hline Gerich et al. [34] & 1 & & & $\begin{array}{l}\text { Arginine; } \\
\text { somatostatin }\end{array}$ & $\begin{array}{l}\text { Basal = zero } \\
\text { no change }\end{array}$ & No glucose change \\
\hline Donowitz $[32,35]$ & 10 & C-terminal & & Alanine & Low basal & No glucose rise \\
\hline Nelson et al. [36] & 6 & C-terminal & & Arginine & $\begin{array}{l}\text { Low basal } \\
\text { No rise }\end{array}$ & $\begin{array}{l}\text { No amino-acid } \\
\text { changes }\end{array}$ \\
\hline Boden et al. [38] & 4 & & Sephadex & Somatostatin & $\begin{array}{l}\text { Basal = zero } \\
\text { No change }\end{array}$ & \\
\hline Botha et al. [42] & 1 & C-terminal & $\begin{array}{l}\text { Sepharose; } \\
\text { Ethanol }\end{array}$ & $\begin{array}{l}\text { Arginine; } \\
\text { hypoglycaemia; } \\
\text { oral glucose } \\
\text { tolerance test; } \\
\text { somatostatin }\end{array}$ & $\begin{array}{l}\text { Normal basal level } \\
\text { No IRG rise } \\
\text { IRG decrease }\end{array}$ & \\
\hline Palmer et al. $[41,43]$ & 5 & C-terminal & Acetone & $\begin{array}{l}\text { Arginine; } \\
\text { Oral glucose } \\
\text { tolerance test; } \\
\text { somatostatin; } \\
\text { hypoglycaemia; } \\
\text { insulin interruption }\end{array}$ & & Variable changes \\
\hline Vranic et al. [40] & 1 & C-terminal & & & Normal basal IRG & \\
\hline Mirouze et al. [44] & 6 & C-terminal & & $\begin{array}{l}\text { Oral glucose } \\
\text { tolerance test }+ \\
\text { somatostatin }\end{array}$ & & \\
\hline \multicolumn{7}{|l|}{ Pancreatitis subjects } \\
\hline Aguilar-Parada et al. [28] & 1 & & & Arginine & No IRG rise & \\
\hline Persson et al. [29] & 1 & & & Hypoglycaemia & No rise & \\
\hline Assan et al. [30] & 16 & $\mathrm{~N}$-terminal & & $\begin{array}{l}\text { Arginine; } \\
\text { hypoglycaemia }\end{array}$ & $\begin{array}{l}\text { Lower IRG } \\
\text { Reduced rise }\end{array}$ & $\begin{array}{l}\text { Reduced glucose } \\
\text { rise } \\
\text { Deeper hypo- } \\
\text { glycaemia }\end{array}$ \\
\hline Kalk et al. [31] & 6 & $\begin{array}{l}\mathrm{C} \text {-terminal and } \\
\mathrm{N} \text {-terminal }\end{array}$ & Ethanol & $\begin{array}{l}\text { Arginine; oral } \\
\text { glucose tolerance } \\
\text { test }\end{array}$ & $\begin{array}{l}\text { Low basal } \\
\text { no change }\end{array}$ & \\
\hline Kalk et al. [31] & 8 & N-terminal & Ethanol & $\begin{array}{l}\text { Oral glucose } \\
\text { tolerance test }\end{array}$ & $\begin{array}{l}\text { Normal IRG } \\
\text { level }\end{array}$ & Glucose rise \\
\hline
\end{tabular}

sent a pattern diametrically opposite to that described in the glucagonoma syndrome [39].

Six other studies, however, have documented the presence of IRG or glucagon-like immunoreactivity in plasma from pancreatectomized patients (a total of 13 subjects) and from some groups of patients with chronic pancreatitis [31, 40, 44]; the $30 \mathrm{~K}$ antiserum was used in most of these reports and plasma samples were submitted to various extraction procedures in three studies [31, 42, 43]. However plasma IRG was not increased by arginine [42,43], adrenaline [42] or cessation of insulin therapy [43]; it was paradoxically 
increased by oral glucose or meals [43]. It was also not wholly or partially suppressed by somatostatin [43, 44]. All these features suggest that plasma IRG in these patients is very different from that measured in other situations.

The significance of 'big plasma glucagon' remains obscure. Some extra pancreatic sources of IRG, particularly the salivary glands, have been documented in man $[45,46]$; most attempts at conversion of 'big plasma glucagon' to 3,500 dalton IRG using proteolytic digestion seem to have yielded fragments of 2,000 daltons rather than 'true' glucagon [33]. Some peptides reacting with the $\mathrm{N}$-terminal antiglucagon antisera are detectable in plasma from pancreatectomized patients and their concentrations may rise after ingestion of glucose [14] but their biological properties remain difficult to interpret. Thus the properties of A cells appear very different in man and also in the macacus Rhesus [47] from that in dogs $[2,3,5,6]$ and several other animal species [4 (review)].

In pancreatectomized patients, the absence of significant glucagon release may contribute to the well-known tendency of these patients to be prone to insulin-induced hypoglycaemia [47].

Acknowledgements. We wish to express our gratitude to Mrs. Josette Boillot for expert technical assistance, Drs. J. R. Girard and $P$. Ferre for friendly advice and help in substrate determinations. Dr. J. Soria contributed to ethanol extraction and lyophilization of samples. This work was supported by Grant No. 46.77 .78 INSERM, Grant from UER Broussais-Hotel Dieu, Association Claude Bernard.

\section{References}

1. Unger RH, Orci L (1976) Physiology and pathophysiology of glucagon. Physiol Rev 56:778-826

2. Vranic M, Reck S, Kawamori S (1974) Increased "glucagon immunoreactivity" in plasma of totally depancreatized dogs. Diabetes 23:905-912

3. Matsuyama T, Foa PP (1974) Plasma glucose, insulin pancreatic and enteroglucagon levels in normal and depancreatized dogs. Proc Soc Exp Biol Med 147:97-102

4. Marre M, Bobbioni E, Suarez M, Reach G, Dubois MP, Assan R (1979) Control of gastric glucagon secretion in the acutely pancreatectomized rat. Diabetes 28:213-220

5. Mashiter K, Harding PE, Chou M, Mashiter G, Stout J, Diamond D, Field JB (1975) Persistent pancreatic glucagon but no insulin response to arginine in pancreatectomized dogs. Endocrinology 96: 678-693

6. Blasquez E, Munoz-Barragan L, Patton GS, Orci L, Dobbs RE, Unger RH (1976) Gastric A cell function in insulin-deprived depancreatized dogs. Endocrinology 99: 1182-1188

7. Morita S, Yip C, Vranic M (1975) Concentrations of immunoreactive glucagon in gastro-intestinal tract of normal and depancreatized dogs. Proc Endocrinol Soc Meeting, June 1975

8. Sutherland EW, De Duve C (1948) Origin and distribution of the hyperglycemic-glucogenolytic factor of the pancreas. J Biol Chem 175:663-674
9. Barnes AJ, Bloom SR (1976) Pancreatectomized man: a model for diabetes without glucagon. Lancet $1: 219-221$

10. Ross G, Lickley L, Vranic M (1978) Extrapancreatic glucagon in control of glucose turnover in depancreatized dogs. Am J Physiol 234: 13-19

11. Müller WA, Brennan MF, Tan MH, Aoki TT (1974) Studies of glucagon secretion in pancreatectomized patients. Diabetes 23 : $512-516$

12. Barnes AJ, Bloom SR, Alberti KGMM, Smythe P, Alford FP, Chisholm DI (1977) Ketoacidosis in pancreatectomized man. N Engl J Med 296: 1250-1253

13. Munoz-Barragan L, Ruffener C, Srikant CB, Dobbs RE, Shannan WA, Baetens D, Unger RH (1977) Immunocytochemical evidence for glucagon containing cells in the human stomach. Horm Metab Res 9: 37-39

14. Sasaki H, Rubalcava B, Baetens D, Blasquez E, Srikant CB, Orci L, Unger RH (1975) Identification of glucagon in the gastro-intestinal tract. J Clin Invest 56: 135-145

15. Müller WA, Girardier L, Seydoux J, Berger M, Renold AE, Vranic M (1978) Extra-pancreatic glucagon and glucagon-like immunoreactivity in depancreatized dogs: a quantitative assessment of secretion rate and anatomical delineation of sources. J Clin Invest 62: 124-132

16. Weir GC, Knowlton SD, Martin DB (1975) High molecular weight glucagon-like immunoreactivity in plasma. J Clin Endocrinol Metab 40:296-302

17. Valverde I, Dobbs RE, Unger RH (1975) Heterogeneity of plasma glucagon immunoreactivity in normal, depancreatized and alloxan-diabetic dogs. Metabolism 24: 1021-1028

18. Alexandre JH, Camilleri JP, Assan R, Guerrieri MT, Bonan A (1977) Indications et résultats de la pancreatectomie totale dans le traitement des pancréatites aigües nécrosantes. Chirurgie 103:858-861

19. Sherwin RS, Fischer M, Hendler R, Felig P (1976) Glucagon and glucose regulation in normal, obese and diabetic subjects. N Engl J Med 294: 455-461

20. Faloona GR, Unger RH (1974) Biological and immunological activity of pancreatic glucagon and enteric glucagon-like immunoreactivity. Isr J Med Sci 10: 1324-1331

21. Heding LG (1971) Radioimmunological determination of pancreatic and gut glucagon in plasma. Diabetologia $7: 10-19$

22. Valverde I, Rigopoulou D, Marco J, Faloona GR, Unger RH (1970) Molecular size of extractable glucagon and glucagonlike immunoreactivity (GLI) in plasma. Diabetes 19: 624.629

23. Kaneto T, Oka H, Munemura M, Yanaihara N, Hashimoto J, Yanaihara C (1974) Radioimmunoassay of human proinsulin $C$ peptide using synthetic human connecting peptide. Endocrinol Jpn 21: 14I-145

24. Huggett ASG, Nixon DA (1957) Use of glucose-oxidase peroxidase and o-dianisidine in the determination of blood and urine glucose. Lancet 2: $368-370$

25. Williamson DH (1970) Alanine. In: Bergmeyer HV (ed) Methods for enzymic analyses. Verlag-Chemie, Weinheim, pp 1634-1636

26. Passonneau JV (1970) Lactate. In: Bergmeyer HV (ed) Methods for enzymic analyses. Verlag-Chemie, Weinheim, pp 1430 1435

27. Snedecor GW (1956) In statistical methods, 5th edn. Iowa State University Press, Ames, pp 49-50

28. Aguilar-Parada E, Eisentraut AM, Unger RH (1970) Pancreatic glucagon secretion in normal and diabetic subjects. Am $\mathbf{J}$ Med Sci 257:415-419

29. Persson I, Gyntelberg F, Heding LG, Boss-Neilsen J (1971) Pancreatic glucagon-like immunoreactivity after intravenous insulin in normals and chronic pancreatitis patients. Acta Endocrinol 67: 401-404

30. Assan R, Tiengo A (1973) Comparative glucagon release in di- 
abetic patients in the presence and in the absence of chronic pancreatitis. Pathol Biol $21: 17-25$

31. Kalk WJ, Vinik AI, Bank S, Buchanan KD, Keller P, Jackson WPU (1974) Glucagon responses to arginine in chronic pancreatitis; possible pathogenic significance in diabetes. Diabetes 23: $257-263$

32. Donowitz M, Hendler R, Spiro HM, Binder HJ, Felig P (1975) Glucagon secretion in acute and chronic pancreatitis. Ann Intern Med 83: 778-781

33. Villanueva ML, Hedo JA, Marco J (1976) Plasma glucagon immunoreactivity in a totally pancreatectomized patient. Diabetologia 12:613-616

34. Gerich JE, Karam JH, Lorenzi M (1976) Diabetes without glucagon. Lancet 1:855

35. Donowitz M, Felig P(1976) Diabetes without glucagon. Lancet $1: 855$

36. Nelson LR, Baldus WP, Rubenstein AH, Gov LW, Service FJ (1979) Pancreatic $\alpha$-cell function in diabetic hemochromatic subjects. J Clin Endocrinol Metab 49:412-415

37. Gerich JE, Langlois M, Noacco C, Karam JH, Forsham PH (1973) Lack of glucagon response to hypoglycaemia in diabetes: Evidence for an intrinsic pancreatic Alpha cell defect. Science 182: 171-174

38. Boden G, Master RW, Trapp V, Owen OE, Rezvani C, Schawartz MI (1979) Effects of acute and chronic glucagon deficiency on aminoacid (AA) metabolism. In: Waldhausl W, Alberti KGMM (eds) 10th Congress of the International Diabetes Federation, vol 481. Excerpta Medica, Amsterdam, pp 26-27

39. Hoist JS, Helland S, Ingemannson S, Bang Pedersen N, von Schenck H (1979) Functional studies in patients with the glucagonoma syndrome. Diabetologia 17: 151-156

40. Vranic M (1976) Elevated gut glucagon-like immunoreactive material in human and experimental diabetes and its suppression by somatostatin. Metabolism 25: 1490-1498

41. Palmer JP, Werner PL, Benson JW, Ensinck JW (1976) Immunoreactive glucagon responses to arginine in three pancreatectomized humans. Metabolism 25:1483-1485

42. Botha JL, Vinik AI, Child PT, Paul M, Jackson WPU (1977)
Pancreatic glucagon-like immunoreactivity in a pancreatectomized patient. Horm Metab Res 9: 199-205

43. Werner PL, Palmer JP (1978) Immunoreactive glucagon response to oral glucose, insulin infusion and deprivation and somatostatin in pancreatectomized man. Diabetes 27: $1005-1012$

44. Mirouze J, Marchal G, Bringer G, De Seguin des Hons TC, Pham Tc, Orsetti A (1979) The antidiabetic properties of somatostatin in the totally pancreatectomized and gastrectomized human. In: Waldhausl W, Alberti KGMM (eds). 10th Congress of the International Diabetes Federation, vol 481. Excerpta Medica, Amsterdam, pp 160-161

45. Lawrence AM, Kirsteins L, Hojvat S, Rubin L, Mitten J, Pearce S, Kacherian R (1976) Submaxillary gland hyperglycemic factor in man and animals: an extrapancreatic glucagon. Clin Res 24:364-367

46. Munoz-Barragan L, Rufener C, Srikant CB, Dobbs RE, Shannan WA, Baetens D, Unger RH (1977) Immunocytochemical evidence for glucagon containing cells in the human stomach. Horm Metab Res 9: 37-39

47. Hoganson G, Huss G, Hoversten G, Hastings R, Jonasson O (1976) Blood glucagon alterations in response to arginine and somatostatin (SRIF) in the pancreatectomized and streptozotocin (STZ) diabetic monkey. Diabetes 25:339 (abstract)

48. Luyckx AS, Giugliano D, Lefebvre PJ (1979) Influence of exogenous glucagon on the metabolic abnormalities of insulindependent diabetics. In: Waldhausl W, Alberti KGMM (eds). 10th Congress of the International Diabetes Federation, vol 481. Excerpta Medica, Amsterdam, pp 158-159

Received: 23 November 1979

and in revised form: 9 July 1981

Dr. R. Assan

Department of Diabetes

Hôpital Bichat

46 rue Henri Huchard

F-75181 Paris, France 